\title{
A NEW SPECIES OF CILIATE, TRICHODINA BRANCHICOLA, FROM SOME FISHES AT PLYMOUTH
}

\author{
By Yogendra R. Tripathi \\ (India State Scholar)
}

From the Plymouth Laboratory

(Text-figs. I, 2)

While examining fishes at Plymouth for parasites I found the gills of eight species of Teleosts infected with a new urceolarid peritrich ciliate which I describe here as Trichodina branchicola n.sp. I also found the same species on rocklings (Ciliata mustela and Gaidopsaurus tricirratus) at Roscoff in March 1947 .

All the fishes were caught at Plymouth and examined fresh, studies being made on living as well as fixed material. The living ciliates were stained with neutral red and methylene blue ( $\mathrm{I}: 5000$ in sea water). The fixatives used were Bouin-Duboscq's fluid, Zenker's fluid (with formalin) and $2 \%$ aqueous osmium tetroxide. The slides were stained in iron-alum-haematoxylin with eosine, or in Delafield's haematoxylin with or without eosine.

The host species and the incidence of infection are shown in Table I.

\begin{tabular}{lcc}
\multicolumn{3}{c}{ TABLE I } \\
Host species & No. examined & No. infected \\
Ciliata mustela (L.) & 26 & 2 I \\
Gaidopsaurus tricirratus (Bloch) & 8 & 6 \\
Cottus bubalis Euphrasen & 4 & 4 \\
Spinachia spinachia (L.) & 4 & 3 \\
Blennius pholis L. & 2 & 2 \\
B. gattorugine Bloch & I & I \\
Trigla lucerna L. & I & I \\
Pleuronectes platessa L. & I & I
\end{tabular}

The intensity of infection was generally high in the first five and low in the last three hosts, but no exact quantitative studies of the parasitic population were made. Ciliata mustela, which is normally heavily parasitized, had a low grade of infection by Trichodina branchicola when caught from the brackish water of the Laira estuary near Plymouth. Four specimens of this fish taken from the estuary after a heavy rainfall had an appreciably low infection.

The following experiment supports the view that reduction in salinity of the water was the operative factor in reducing the parasitic population. The infected gills of Ciliata mustela were placed in diluted sea water ( 75 c.c. sea water and 25 c.c. distilled water) and it was found that after $3 \mathrm{hr}$. the ciliates were dead. The experiments were conducted in a bath of circulating sea water to ensure the requisite low temperature. Casual observations have repeatedly shown that Trichodina branchicola n.sp. is far more sensitive to changes of 
temperature and salinity than its hosts. This evidence tends to show that this species of Trichodina is a stenohaline organism and will not be found on freshwater fishes.

After removal from its fish host $T$. branchicola does not survive in sea water for more than $2-3 \mathrm{hr}$.: it may live much longer on the dead host provided that it is kept at a low enough temperature. I have observed the ciliates still moving $32 \mathrm{hr}$. after the infected gills were removed from Ciliata mustela and had been placed in a refrigerator, although the sea water covering them had a thin film of ice. Richardson (I938) has done some experiments to show the viability of Cyclochaeta domerguei Wallengren, under different temperatures and salinity. Fresh-water fishes when infected with Trichodina spp. in the hatcheries are cured of the infection by a bath in saline water, or by putting them 'for I hour in a solution composed of I part of formalin (40\%) to 4000 parts water' (Davis, I947).

In Ciliata mustela and Gaidopsaurus tricirratus the only other gill parasite was a species of Gyrodactylus. This monogenean occurred as a moderate infection irrespective of the presence of Trichodina branchicola and there is no reason to think that they are incompatible.

In one Spinachia spinachia examined on 9 July 1946 the gills were infected with a species of Amoeba (6-II $\mu$ in diameter) and hardly a dozen Trichodina branchicola were present. None was found to be infected by the Amoeba. The high infection of Amoeba was associated with hyper-secretion of mucus. Trichodina branchicola, normally a very actively moving animal, was hampered in its movements by the presence of the viscous mucus on the gills, and this may account for the unusually low infection. Chatton (I9I0) has described Amoeba mucicola infecting Trichodina labrorum Chatton I910, from the gills of Symphodus tinca, but does not mention any pathological effect on the ciliate.

\section{MORPHOLOGY}

The shape of the organism is surprisingly variable. The oral or anterior end is strongly arched and the saucer shape of the posterior or aboral end is maintained by the 'skeletal complex', which in life is applied to the gill surface of the host (Figs. I $b ; 2 a, b)$. The general shape may be hemispherical or subspherical. When viewed from above the organism is round $(30-53 \mu$ in diameter) (Fig. I $a, b$ ). Its height (antero-posterior) is $22-36 \mu$.

In the genus Trichodina there are two rings of cilia, an anterior oral and a posterior aboral ring - the latter is the chief organ of locomotion. In between these two rings of cilia is the velum - a fold of protoplasmic pellicle, capable of great extensions and contractions (Fig. $2 a, b$ ). It attains its greatest size when the animal is crawling on the gills or moving freely in the water (as seen on the slide under the microscope), and almost disappears when the animal is motionless or nearing death. 
On the posterior surface, internal to the aboral ring of cilia, lies the 'skeletal complex' composed of the outer striated and the inner denticulate rings (Figs. I $b ; 2 b, c)$.

The skeletal complex and the centre of the ring are covered by a thin protoplasmic pellicle (Fig. $2 b$ ). The denticulate ring (IO-I9 $\mu$ in diameter) consists of 20-26 denticles. The following table shows the percentage of individuals with different numbers of denticles and the average diameter of the ring. These measurements are from I42 individuals from a single Ciliata mustela.

No. of denticles

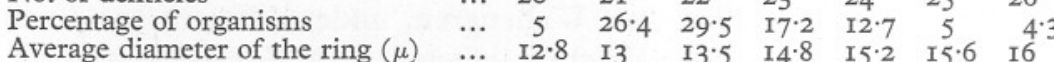

$\begin{array}{llllllll}\ldots & 20 & 21 & 22 & 23 & 24 & 25 & 26\end{array}$
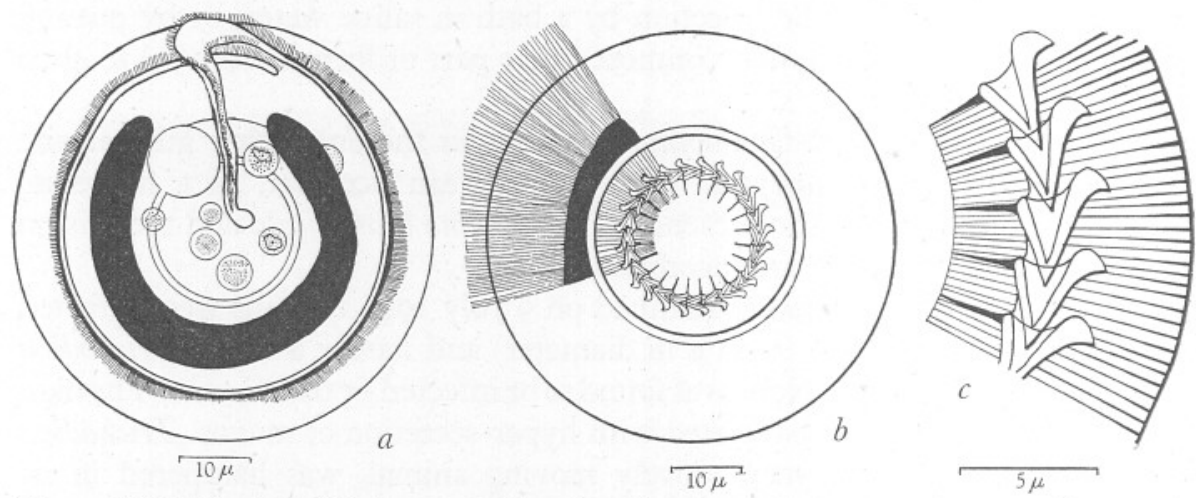

Fig. I. Trichodina branchicola: $a$, anterior view showing oral groove and contractile vacuole and macronucleus; $b$, posterior view showing the skeletal complex and aboral cilia; $c$, portion of skeletal complex (further magnified).

The highest percentage of individuals is with 22 denticles; individuals with $2 \mathrm{I}$ and 23 denticles coming second and third. The size of the ring increases with the number of the denticles. Each denticle (Fig. I $c$ ) is cone-shaped, $\mathrm{I} \cdot 5-2.0 \mu$ thick and $3.5 \mu$ long, with a broad curved hook $(2.3 \mu$ long) on the outer side. The concave side of the hook is slightly thicker than the convex side. Each hook is attached to the cone at an angle like an oar. On the inner side of the cone there is a ray $(3.2 \mu$ long) pointing centrally and slightly anteriorly. It is thicker at the base, tapering towards the centre. In young Trichodina branchicola which has just undergone fission the number of denticles is halved, being IO-I3 only. The outer hook is a little in front of the inner ray, as in $T$. truttae Mueller, and not exactly opposite, as in $T$. pediculus Ehrb. as described by Mueller (1937). The denticulate ring stains beautifully red with eosine and this helps very much in counting the number of denticles under the oil immersion lens.

External and somewhat anterior to the denticulate ring is a striated ring band $19-33 \mu$ in diameter (Figs. $\mathrm{I} b, c ; 2 c$ ). There are six striae to each denticle. Each stria extends inwards as far as the inner ray. Each also is 
connected with the ciliary girdle by a strand of material which takes up the eosine stain less readily than the stria. Mueller (1938) supposed these structures to be myonemes. The outer borders of the striae fuse to form the edges of the adhesive disk. Each stria is thicker at the outer ends and tapers towards the centre. The ciliate secures itself to the gill surface with the adhesive disk. The skeletal complex is capable of movement as a whole in the horizontal plane but whether it can move in the antero-posterior direction as well is not clear.

The aboral cilia, $15-20 \mu$ long, are fused at their base to form a thin membranelle, their distal ends being free (Figs. $\mathrm{I} b ; 2 c$ ). In $T$. pediculus Ehrb., $T$. steinii (Clar. \& Lach.) and T. renicola (Mueller) the cilia are fused to form a series of membranelles. In the present species there is one continuous membranelle like that in T. spheroidesi Padnos \& Nigrelli. The cilia do not fuse to form any membranelle in T. halli Padnos \& Nigrelli and T. urinicola Fulton.

The oral groove runs round the anterior surface of the organism and makes little more than one anti-clockwise turn and then descends into the vestibulum which is connected with the gullet at its posterior end (Figs. $1 a ; 2 b$ ). The vestibulum descends obliquely and makes an angle of nearly $45^{\circ}$ with the vertical axis of the organism. The base of the groove is slightly thickened and from its edges two parallel rows of cilia arise which are fused at their bases to form two parallel membranelles. The outer cilia are slightly longer than the inner. The inner membranelle ends at the entrance of the vestibulum. In the anterior three-quarters of the vestibulum the cilia are curved at their free ends and fused at their bases. The wave of movement starts at the anterior end and passes towards the gullet. In the last quarter of the vestibulum the cilia are longer and beat quickly towards the gullet. The undulatory motion of the cilia of the oral groove appears to form four waves in the whole circumference. The gullet is devoid of any cilia. The food vacuoles arise hear the fundus of the gullet and then move peripherally in spirals. When stained intra vitam with neutral red ( $\mathrm{I}: 5000$ in distilled water) the food vacuoles take the stain in $5 \mathrm{~min}$. The young vacuoles stain yellowish and later on become pinkish. This shows a change in the $\mathrm{pH}$ content of the food vacuoles from basic to acidic, i.e. at a rough estimate initially at $\mathrm{pH} 8$ or more to $\mathrm{pH} 7 \cdot 5$ or thereabout. The food vacuoles are mostly in the anterior half of the body. The food of the ciliate consists of desquamated epithelial cells and erythrocytes of the host fish. Diller (I928) states that Trichodina on the gills of tadpoles feed only on bacteria.

The contractile vacuole is $6 \cdot 0-\mathrm{II} \cdot 5 \mu$ in diameter and situated near the vestibule (Fig. I $a$ ). It pulsates every $30-35 \mathrm{sec}$. In T. urinicola, Fulton (1923) records that the pulsation is very sluggish, while in T. pediculus Ehrb., Mueller (I937) records the pulsation at the interval of IO-I2 sec. The opening of the vacuole is not clear in the living or fixed specimens, but in sections it can be seen as a very thin short duct opening in the anterior part of the vestibulum. When the organism is stained intra vitam the vacuole does not take any stain. 
No accessory vacuoles are present in any species of Trichodina such as have been reported for Cyclochaeta domerguei (Wallengren) by MacLennan (I939) and in various vorticellids by Fauré-Fremiet (I925).

The macronucleus is situated in the posterior half of the body, is horseshoeshaped, and lies parallel to the plane of the 'skeletal complex' (Figs. I $a ; 2 a$ ). It is $6.0-10.5 \mu$ thick in the centre and somewhat thinner at the ends. The two ends of the nucleus are separated by the vestibulum and the contractile vacuole. The micronucleus is situated in a pocket in the macronucleus on its outer edge and can be seen only in the sections. During vegetative life the macronucleus is uniformly granular.

The body of the ciliate is covered by a thin protoplasmic pellicle. Within this is the dense granular layer of the protoplasm. The endoplasm is less granular and has many food vacuoles and the contractile vacuole.

\section{LOCOMOTION}

The organism moves by the help of the posterior cilia. Each cilium moves with a gyratory motion while the resultant movement of the whole ring appears as a wave motion. The animal rotates in a clockwise or anti-clockwise direction and moves very quickly with the posterior end forwards when swimming freely in water. There does not seem to be any relation between gyratory and rotatory motion. During movement the body is very much constricted anteroposteriorly and the velum increases in size. When the animal is 'browsing' on the gill with its adhesive disk in contact with the gill surface, it does not move very quickly.

\section{PATHOGENIC EFFECT}

When Trichodina settles on the gills and makes itself secure by the application of the adhesive disk then considerable local irritation must be caused, and this seems to bring about the desquamation of the epithelial cells of the gills. No very marked pathogenic effect was observed on the gills of the fishes examined during the course of the present studies, though there is no doubt that considerable harm could be done to the host if the ciliates were present in large numbers. At times, in fresh-water fish hatcheries, some species of Trichodina cause epidemic mortality.

\section{REPRODUCTION}

As a rule in the family Urceolaridae reproduction is by binary fission, though conjugation and endomixis also take place. Some stages of fission have been observed in $T$. branchicola. Preparatory to the fission the macronucleus becomes round and then oblong and stains deeply with haematoxylin. The shape of the organism changes and it too becomes oblong and later on dumbbell-shaped. The micronucleus divides into two and can be seen lying on the outside of the macronucleus (Fig. $2 d$ ). There is a constriction in the adhesive disk, and then in the denticulate ring. The macronucleus and the whole body then divide into two daughter individuals. 
The young individual has about half the adult number of the denticles in the denticulate ring. The old vestibulum persists in one of the daughter individuals while a new one seems to develop in the other. Peshkowsky (1923) states that the oral cilia, gullet and contractile vacuole are absorbed during division in T. mitra and T. steinii. Padnos \& Nigrelli (1942) report that these organs definitely remain in $T$. spheroidesi during the fission, as occurs in the present species. The fate of the contractile vacuole could not be followed, though according to Padnos \& Nigrelli it cleaves at the same time as the macronucleus in T. spheroidesi. Diller (1928) states that the contractile vacuole probably persists in one of the daughter individuals in Trichodina sp. on the gills of tadpoles.

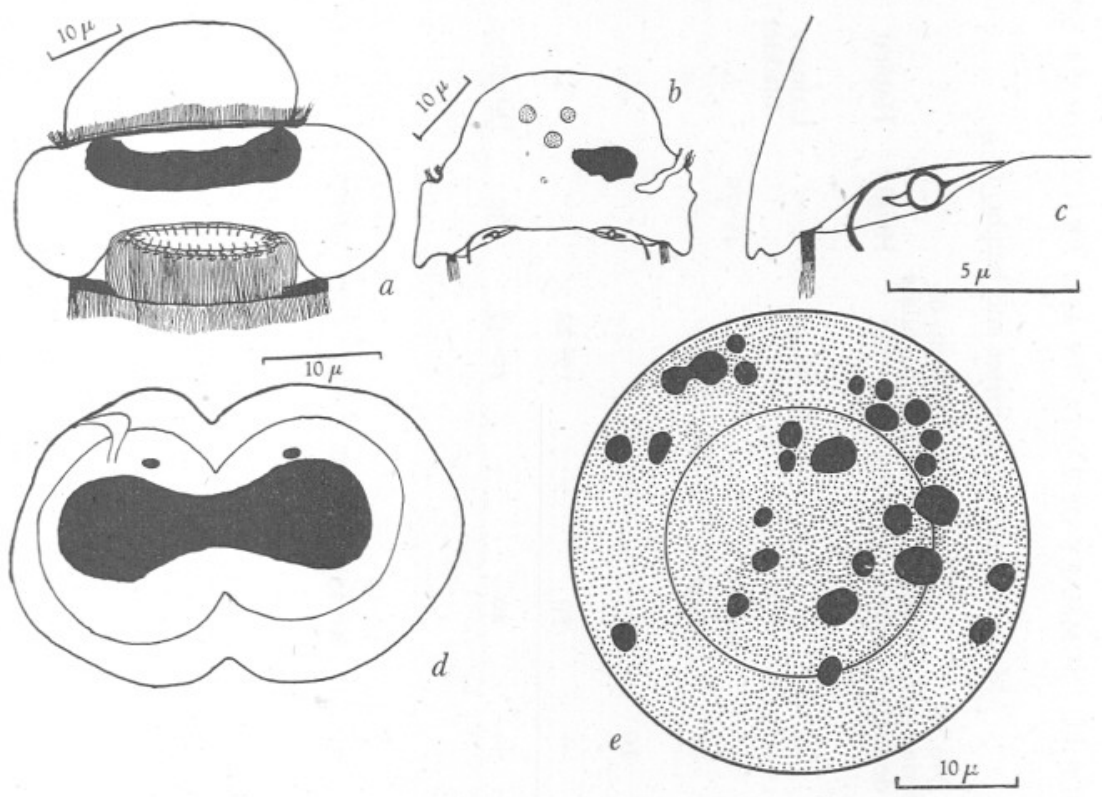

Fig. 2. Trichodina branchicola: $a$, side view; $b$, vertical section showing food vacuoles and oral groove; $c$, portion of the same showing skeletal complex in section; $d$, individual undergoing fission, showing macro- and micro-nuclei and a part of the oral groove; $e$, macronucleus broken up into small fragments.

The young individual has the shape of the adult. The 'skeletal complex' arises de novo in the adult exterior to the smaller skeletal complex inherited from the parent which is gradually absorbed. Various stages in the development of the new denticulate ring are seen and they confirm fully the findings of Fauré-Fremiet \& Thareaux (1944, pl. I, figs. I-5). At first the central cone is formed, then the outer hook and lastly the inner ray. At first the denticle is thin but gradually it becomes thick. The young individuals, with one ring only, measure $25-33 \mu$ in diameter, the diameter of the denticulate ring being $6.5-10 \mu$. The number of denticles is IO-I3. The macronucleus is round or 


\section{Table II. Summary of Data on all TRICHODINA Species}

Measurements (of diameter and height) in $\mu$

\begin{tabular}{|c|c|c|c|c|c|c|c|c|}
\hline Species & $\begin{array}{l}\text { No. of } \\
\text { denticles }\end{array}$ & $\begin{array}{l}\text { No. of } \\
\text { striae per } \\
\text { denticle }\end{array}$ & $\begin{array}{l}\text { Total } \\
\text { diam. }\end{array}$ & $\begin{array}{l}\text { Diam. of } \\
\text { striated } \\
\text { ring }\end{array}$ & $\begin{array}{l}\text { Diam. of } \\
\text { denticulate } \\
\quad \text { ring }\end{array}$ & Height & Habitat & Host \\
\hline \multicolumn{9}{|l|}{ ENDOPARASITES: } \\
\hline T. urinicola Fulton, 1923 & $26-36$ & - & - & - & $34-35$ & - & $\begin{array}{l}\text { Urinary } \\
\text { bladder }\end{array}$ & Triton cristatus, Bufo sp. \\
\hline T. okajimae Ibara, I93I & $34-38$ & - & $40-60$ & $20-40$ & - & $45-70$ & m 1 & Hynobius tokyoensis \\
\hline $\begin{array}{l}T .[V .] \text { renicola (Mueller, I93I) } \\
\text { n.comb. }\end{array}$ & 56 & - & $70-96$ & - & - & - & " & Esox niger \\
\hline $\begin{array}{l}T .[V \text {.] nephritica (Mueller, } \\
\text { I938) n.comb. }\end{array}$ & $36-40$ & Io & - & $62-75$ & - & - & ” & Esox masquinongy \\
\hline $\begin{array}{l}\text { T. vesicularum Fauré-Fremiet, } \\
\text { I } 943\end{array}$ & $2 I-33$ & - & 50 & 一 & $19-22$ & - & " & Triton cristatus, $T$. palmatus \\
\hline $\begin{array}{l}\text { T. fariai Da Cunha \& Pinto, } \\
\text { I } 928\end{array}$ & $24-28$ & - & 40 & - & $20-42$ & 32 & Intestine & Spheroides testudineus \\
\hline \multicolumn{9}{|l|}{ ECTOPARASITES: } \\
\hline T. labrorum Chatton, I9ro & 21 & - & $30-34$ & - & - & $18-22$ & Gills & Symphodus tinca and $S$. melops \\
\hline $\begin{array}{l}\text { T. chelidonichthys Fantham, } \\
\text { I } 930\end{array}$ & 30 & - & $30-45$ & I9-32 & - & $19-27$ & , & Chelidonichthys cupensis \\
\hline T. mugilis Fantham, I930 & 32 & - & $33-34$ & $23-28$ & - & $14-20$ & , 1 & Mugil capito \\
\hline T. blennii Fantham, I930 & $24-32$ & 5 & $40-45$ & $24-27$ & 一 & $20-32$ & $\begin{array}{l}\text { Gills and } 1 \\
\text { pericardium }\end{array}$ & Blennius cornutus \\
\hline T. clini Fantham, 1930 & 24 & - & 37 & 20 & - & 20 & m & Clinus anguillaris \\
\hline $\begin{array}{l}\text { T. halli Padnos \& Nigrelli, } \\
\text { I942 }\end{array}$ & $26-34$ & - & $45-86$ & $4 I-8 I$ & $30-54$ & - & $\begin{array}{l}\text { Gills and } \\
\text { skin }\end{array}$ & Spheroides maculatus \\
\hline $\begin{array}{l}\text { T. spheroidesi Padnos \& } \\
\text { Nigrelli, } 1942\end{array}$ & $2 I-3 I$ & - & $17-54$ & $18-32$ & $14-22$ & $12-42$ & " & " \\
\hline T. branchicola n.sp. & $20-26$ & $6-8$ & $30-54$ & $19-33$ & $10-20$ & $22-36$ & Gills & See p. 440 \\
\hline
\end{tabular}

Habitat of host

Fresh

water

,

,

Marine

, 


\section{T. pediculus Ehrenberg, I838}

T. steinii Clarapede \&

Lachmann, 1858

$T$. [C.] spongillae Jackson,

I875, n.comb.

$T$. [C.] domerguei (Wallengren, I897), n.comb.

T. truttae Mueller, 1937

T. myakkae Mueller, 1937

T. [C.] guberleti MacLennan, I939, n.comb.

T. tenuidens Fauré-Fremiet, 1943

T. discoidea Davis, 1947

T. platyformis Davis, 1947

T. vallata Davis, 1947

T. fultoni Davis, 1947

T. symmetrica Davis, 1947

T. californica Davis, 1947

T. tumefaciens Davis, I947

T. bulbosa Davis, 1947

T. brusiformis Davis, 1947

\section{I6-26}

$2 I-26$

37

I 8-25

28-3I

I $7-24$

20

4-5

28-32

27-37

I8-30

26-35

I8-2I

$25-30$

I2-I4

$2 \mathrm{I}-28$

$25-32$

19-26

19-24

24-27

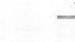

6-8

IO

10

\section{0}

IOO

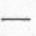

24-35

$13-22$

$38-50$

29-30

$22-26$

25-35

I8-23

IO-I2

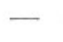

Body

surface

Various fresh-water fishes, tad- Fresh poles and salamanders; Hydra water

Body Polycelis nigra, Dugesia lugubris,

surface Polycelis cornuata

Inside Spongilla fluviatilis

the body

- $\quad \frac{1}{5}$ th of Gills On various fishes

Salmo clarkii

Aplites salmoides, Ictiobus bubalus, Carpoides carpio, Salvalinus fontinalis

Richardsonius balteatus, Apocope oscula carringtoni

Gasterosteus aculeatus

4I-55 ,

Gills

Lepomis macrochirus, Pomoxis sparoides, Ambloplites rupestris, Ictalurus punctatus

, Margariscus margarita, Rhinichthys atronasus

Ictalurus punctatus

Huro salmoides, Micropterus dolomieu, Lepomis macrochirus, Ambloplites rupestris, Salmo irideus

Ictalurus punctatus, Margariscus margarita, Rhinichthys atronasus

25-33

I4-I8

Oncorhynchus tschawytscha

Cottus bairdii

Margariscus margarita

Ambloplites rupestris 
ellipsoidal at first but gradually becomes horseshoe-shaped. No stages of conjugation were observed. I have found one individual in which the nucleus is broken up into small spherules (Fig. $2 e$ ) and is very much like the fig. I4, pl. II of Padnos \& Nigrelli (1942) and figs. 29-36, pl. 3 of Diller (1928). In the absence of other stages it is very difficult to interpret correctly the nucleus phase of this individual.

The rate of fission during the summer increases, for it is only during the months of March to August that various individuals undergoing fission were observed. No quantitative population count was done to find the percentage of the dividing forms. Only one young individual was observed during the period September 1946-March 1947, while several have been observed from April 1947 to August 1947 .

\section{Discussion ON TAXONOMY}

Fauré-Fremiet (1943) has recently given a very good systematic review of the family Urceolaridae. He retains only two genera, Trichodina Ehrb. and Urceolaria Stein., in this family; and he relegates the genus Cyclochaeta Jackson as a sub-genus of Trichodina, and Leiotrocha Fabre-Domergue as a sub-genus of Urceolaria.

The members of the genus Trichodina are generally found as ectoparasites on the gills and skin of fishes and tadpoles, and as endoparasites in the urinary bladder of fishes and Urodela and rarely in Anura. Mueller (1938) has created a new genus Vauchomia for endoparasitic urceolarids. The only difference between Vauchomia and Trichodina, according to Mueller, is that the former has a system of 'myonemes' and the oral groove makes more than two turns. The shape of the denticulate ring is similar in both these genera. The 'myonemes' have, however, since been described in additional species of ectoparasitic Trichodina. The distinction, therefore, does not strictly hold, and the name Vauchomia is relegated to a synonym of Trichodina.

In distinguishing the different species of the genus Trichodina (which now includes Cyclochaeta and Vauchomia as well) the size, shape and the number of the denticles are of great value. Fauré-Fremiet (I943, p. I63) and Davis (1947, p. 7) have also emphasized this point. Biometrical studies on the variation in the number of denticles in a population of Trichodina are of great help in finding out whether that particular population contains one or two species of Trichodina. Mueller (I937) pointed out that Wallengren (I897) was probably dealing with more than one species of Trichodina which he described as T.pediculus. Recently Fauré-Fremiet (I943), on the basis of his biometrical studies, has pointed out that there are really two species of Trichodina on the skin of Gasterosteus aculeatus. The one with 20-26 denticles is T. [Cyclochaeta] domerguei (Wallengren), and the other with 30-34 denticles he named $T$. tenuidens. The variation in the number of denticles is the same in $T$. [Cyclochaeta] domerguei and T. branchicola n.sp., but the size of the denticles and the shape of the body differ in the two species. 
At present there are 31 species of Trichodina out of which I6 are freshwater, 8 marine, 6 endoparasites in the urinary bladder, and one in the intestine of Spheroides testudineus. In Table II the measurements, habitats and hosts of all the species of Trichodina are given.

I take this opportunity to thank the Director and the Staff of the Plymouth Laboratory for their kind interest and facilities offered to me. My hearty thanks are due to Miss N. G. Sproston, under whose guidance this work was done, for her helpful criticisms and encouragement, and to Miss T. Skilton for her help in translating the French papers.

\section{SUMMARY}

The morphology and reproduction of Trichodina branchicola n.sp. are described. Its total diameter is $30-54 \mu$, and its height is $20-36 \mu$; the diameter of the striated ring is $19-33 \mu$, and the diameter of the denticulate ring Io-20 $\mu$. There are 20-26 denticles in the ring, with 6-8 striations to each denticle. The denticles measure $\mathrm{I} \cdot 5-2 \mu$ in thickness, $3.5 \mu$ in length, each with a broad outer hook $2 \cdot 3 \mu$ long and an inner ray $3 \cdot 2 \mu$ long. The aboral cilia are fused at their base to form a complete membranelle.

This organism is found on the gills of the following marine fishes at Plymouth: Ciliata mustela, Gaidopsaurus tricirratus, Cottus bubalis, Spinachia spinachia, Blennius pholis, B. guttorugine, Trigla lucerna and Pleuronectes platessa.

The genus Vauchomia Mueller I938 is regarded as a synonym of Trichodina.

\section{REFERENCES}

Chatton, E., I9ro. Protozoaires parasites des branchies des labres; Amoeba mucicola Chatton, Trichodina labrorum n.sp. Appendice: Parasite des Trichodines. Arch. Zool. exp. gen., T. v, pp. 239-66.

Cunha, M. DA \& Pinto, C., I928. Trichodina fariai n.sp., cilié péritriche endoparasite de poisson marin. C.R. Soc. Biol. Paris, T. xcvir, pp. I570-I.

Davis, H. S., I947. Studies of the protozoan parasites of freshwater fishes. Fishery Bull. Fish and Wildlife service, Vol. LI, No. 4I, 29 pp., I4 pls.

Diller, W. F., I928. Fission and endomixis in Trichodina from tadpoles. Fourn. Morph., Vol. XLVI, pp. 52I-6I.

Fantham, H. B., I930. Some parasitic protozoa found in South Africa. XIII. S. Afr. F. Sci., Vol. xxvII, pp. 376-90.

FAURÉ-FREMIET, E., I925. La structure permanente de l'appareil excréteur chez quelques Vorticellides. C.R. Soc. Biol. Paris, T. xcIII, pp. 500-3.

— 1943. Etude biométrique de quelques Trichodines. Bull. Soc. Zool. France, T. LXVIII, pp. 158-69.

Fauré-Fremiet, E. \& Thareaux, J., I944. Protéines de structure et cytosquelette chez les Urcéolarides. Bull. Biol. France et Belg., T. LXxviII, pp. I43-56.

Fulton, J. F., I923. Trichodina pediculus and a new closely related species. Proc. Boston Soc. Nat. Hist., Vol. xxxvII, pp. I-29. 
IBARA, Y., I93I. Trichodina okajimae n.sp., a new species of Trichodina from Salamanders. F. Elisha Mitchell Sci. Soc., Vol. xuvI, pp. 2I4-I7.

JACKSON, W. H., I875. On a new peritrichous infusoria. (Cyclochaeta spongillae.) Quart. F. Micr. Sci., Vol. xv, pp. 243-9.

MACLENNAN, R. F., I939. The morphology and locomotor activities of Cyclochaeta domerguei Wallengren (Protozoa). Fourn. Morph., Vol. Lxv, pp. 24I-56.

MUelleR, J. F., I932. Trichodina renicola (Mueller, I93I), a ciliate parasite in the urinary tract of Esox niger. Roosvelt Wildlife Ann., Vol. III, pp. I39-54.

- 1937. Some species of Trichodina (ciliate) from freshwater fishes. Trans. Amer. Micr. Soc., Vol. LVI, pp. I77-84.

- I938. A new species of Trichodina (ciliate) from the urinary tract of the muskelonge, with reparation of the genus. Fourn. Parasit., Vol. xxrv, pp. 25 I-8.

Padnos, M. \& Nigrelli, R. F., I942. Trichodina spheroidesi and Trichodina halli spp.nov., parasitic on the gills and skin of marine fishes, with special reference to the life history of T. spheroidesi. Zoologica, Vol. xxvII, No. I2, pp. 65-72.

Peshkowsky, L., 1923. Biological and structural features of Trichodina. Arch. Russes. protist. Vol. II, pp. 249-79 (Russian with English summary).

RICHARDSON, L. R., I938. Observation on trichodinid infection (cyclochaetosis) of Salvelinus fontinalis (Mitchell). Trans. Amer. Fish. Soc., Vol. Lxvir, pp. 228-3I.

Wallengren, H., I897. Zur Kenntnis der Gattung Trichodina Ehrb. Biol. Zbl., Bd. xvII, pp. 55-65. 